\title{
Wzbogacenie w REE utworów osadowych w wybranych rejonach obrzeżenia mezozoicznego Gór Świętokrzyskich - obiecujące dane wstępne i potrzeba dalszych badań
}

\author{
Stanisław Z. Mikulski ${ }^{1}$, Paweł Brański ${ }^{1}$, Grzegorz Pieńkowski ${ }^{1}$, \\ Rafał Małek $^{1}$, Karol Zglinicki ${ }^{1}$, Andrzej Chmielewski ${ }^{1}$
}

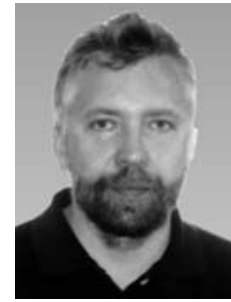

S.Z. Mikulski

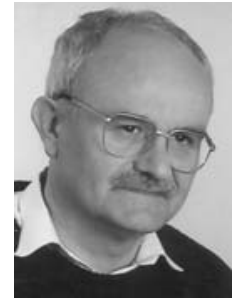

P. Brański

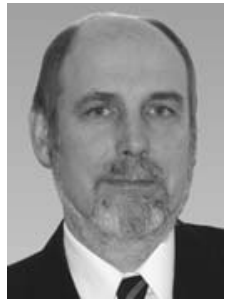

G. Pieńkowski

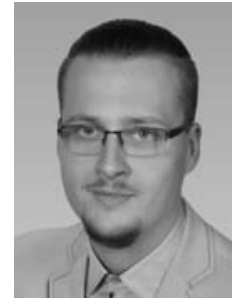

R. Małek

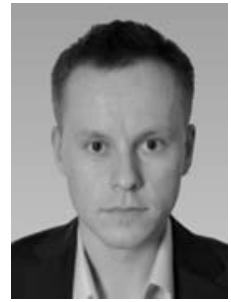

K. Zglinicki

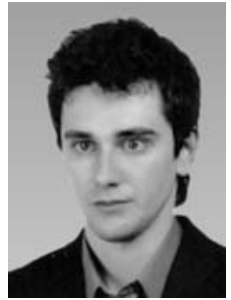

A. Chmielewski

REE enrichment of sedimentary formations in selected regions of the Mesozoic margin of the Holy Cross Mountains - promising preliminary data and more research needed. Prz. Geol., 69: 379-385; doi: 10.7306/2021.21

A b s t r a c t. The main task of research was a quantitative and qualitative identification of rare earth elements within various Mesozoic sediments in the surroundings of the Holy Cross Mountains. Over 100 samples from archive boreholes, outcrops and mining waste were analysed using modern methods, like portable XRF, geochemical analysis (ICP-MS), electron microprobe and SEM. Results show enrichments of REE concentrations in sedimentary rock samples from the Niektań PIG-1 borehole ( $\Sigma R E E$ up to 0.95\%), Miedary out-

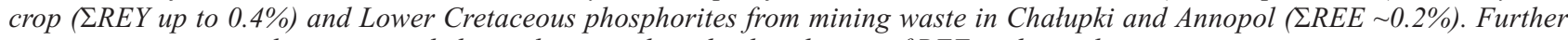
investigation is strongly recommended in order to explain the distribution of REE in the study areas.

Keywords: rare earth elements, siliciclastic deposits, Upper Triassic-Lower Jurassic, Lower Cretaceous (Albian-Cenomanian) phosphorites

Przedstawione w artykule wyniki badań uzyskano podczas realizacji tematu pt. Ocena występowania REE $i$ niektórych pierwiastków śladowych $w$ Polsce, stanowiącego część większego projektu pt. Wsparcie działań Głównego Geologa Kraju w zakresie prowadzenia Polityki Surowcowej Państwa. Projekt realizowano w okresie od 01.07.2017 r. do 30.09.2020 r. w ramach zadań państwowej służby geologicznej (PSG) w Państwowym Instytucie Geologicznym - Państwowym Instytucie Badawczym (PIG-PIB). Celem jego wykonania było podsumowanie obecnego stanu wiedzy oraz dokonanie pilotażowej oceny perspektyw złożowych wystąpień REE w różnych jednostkach geologicznych w Polsce (Mikulski i in., 2021).

\section{ZAKRES I METODYKA BADAŃ}

Przedmiotem prac analitycznych było ponad 100 próbek skał. Większość z nich pochodziła $\mathrm{z}$ archiwalnych otworów wiertniczych, które nawierciły mezozoiczne skały klastyczne powstałe w polskiej części basenu epikontynentalnego (ryc. 1).

Interesujące pod względem zawartości REE są pojedyncze miejsca znajdujące się na Niżu Polskim w obrzeżeniu Gór Świętokrzyskich. Obecne są tam formacje skał klastycznych, w tym mułowce ilaste i piaszczyste zalicza- ne do triasu górnego i jury dolnej wzbogacone miejscami (górny trias) w substancje kostne, oraz płytkomorskie osady fosforytonośne kredy dolnej (alb-cenoman). W celu wyznaczenia miejsc pobrania próbek w profilach rdzeni oraz prześledzenia zawartości pierwiastków w wyznaczonych interwałach posłużono się przenośnym spektrometrem XRF (Delta Premium firmy Olympus). Wytypowane próbki były przedmiotem badań geochemicznych REE za pomocą techniki ICP-MS. Zgodnie z definicją Międzynarodowej Unii Chemii Czystej i Stosowanej (International Union of Pure and Applied Chemistry - IUPAC) pierwiastki ziem rzadkich (Rare Earth Elements - REE) to grupa 17 pierwiastków, w skład której wchodzi 15 lantanowców oraz 2 skandowce - Y oraz Sc. W niniejszym artykule, podobnie jak i w źródłowym opracowaniu (Mikulski i in., 2021), przyjęto, że LREE składają się z: La, Ce, Pr, Nd, Pm (ten ostatni pierwiastek - promet, ze względu na krótki czas rozpadu, nie występuje na Ziemi i nie jest uwzględniony w analizach) i Sm, a do HREE zaliczono: Eu, Gd, Tb, Dy, Ho, Er, Tm, Yb oraz Lu, dla niektórych obszarów również itr. W statystykach opisowych oraz na rycinach graficznych każdorazowo dokładnie określono zakres przedstawionych informacji (REE i/lub REY oraz HREE i/lub HREY). Na wybranych próbkach wykonano również badania mineralogiczne przy użyciu mikroskopu polaryzacyj-

Państwowy Instytut Geologiczny - Państwowy Instytut Badawczy, ul. Rakowiecka 4, 00-975 Warszawa; stanislaw.mikulski@pgi.gov.pl; pawel.branski@pgi.gov.pl; grzegorz.pienkowski@pgi.gov.pl; rafal.malek@pgi.gov.pl; karol.zglinicki@pgi.gov.pl; andrzej.chmielewski@pgi.gov.pl 


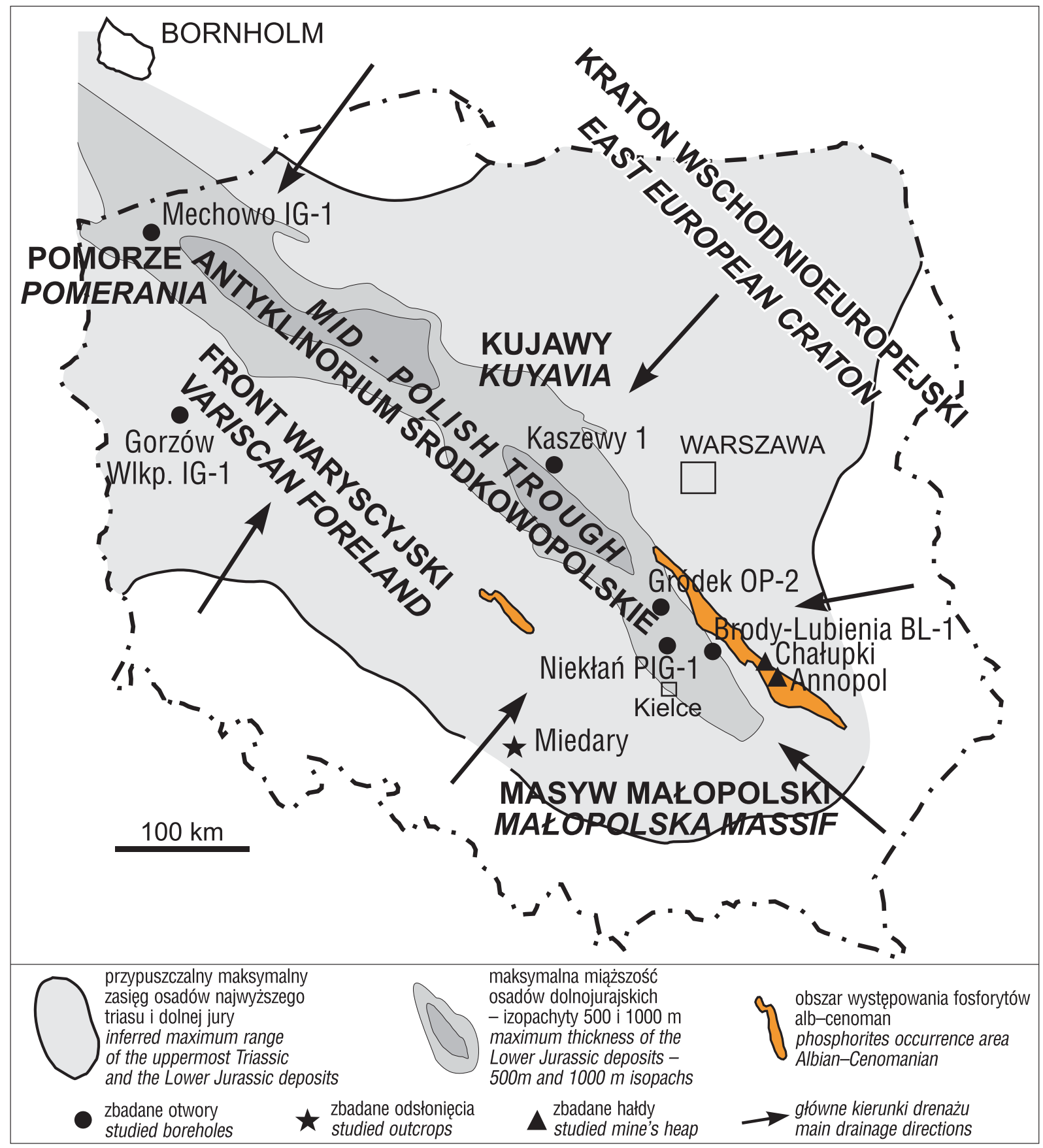

Ryc. 1. Lokalizacja najciekawszych pod względem zawartości REE miejsc pobrania próbek w obrzeżeniu mezozoicznym Gór Świętokrzyskich. Zasięg utworów T3-J1 wg Pieńkowskiego (2004) oraz dolnokredowych fosforytów wg Gąsiewicza (2020) Fig. 1. Location of the most interesting sampling sites in terms of REE content in the Mesozoic margin of the Holy Cross Mountains. The range of the T3-J1 deposits acc. to Pieńkowski (2004) and Lower Cretaceous phosphates acc. to Gąsiewicz (2020)

nego i mikrosondy elektronowej (Cameca SX-100 ze spektrometrem WDS), które były poprzedzone obserwacjami na skaningowym mikroskopie elektronowym (Leo-1430 (ZEISS) z detektorem EDS.

\section{NAJBARDZIEJ INTERESUJACE WYNIKI OZNACZEŃ ZAWARTOSCI REE}

Pomimo że większość dotychczas badanych skał osadowych jury dolnej i triasu górnego w dawnym basenie polskim ma charakterystykę geochemiczną zbliżoną do charakterystyki standardowych, postarchaicznych łupków australijskich (PAAS, McLennan, 2001), to lokalnie stwierdzono znaczne wzbogacenie w REE (Mikulski i in., 2014, 2021; Brański, Mikulski, 2016; Brański, 2018). Poniżej przedstawiono miejsca najciekawsze pod względem zawartości REE w obrzeżeniu mezozoicznym Gór Świętokrzyskich. Są to: otwór wiertniczy Niekłań PIG-1, odsłonięcie Miedary oraz hałdy poeksploatacyjne w Annopolu i Chałupkach (ryc. 1).

\section{Otwór wiertniczy Niekłań PIG-1}

Najciekawszym miejscem pod względem zawartości REE okazał się odcinek retycki profilu otworu Niekłań PIG-1 w północnym obrzeżeniu Gór Świętokrzyskich. 


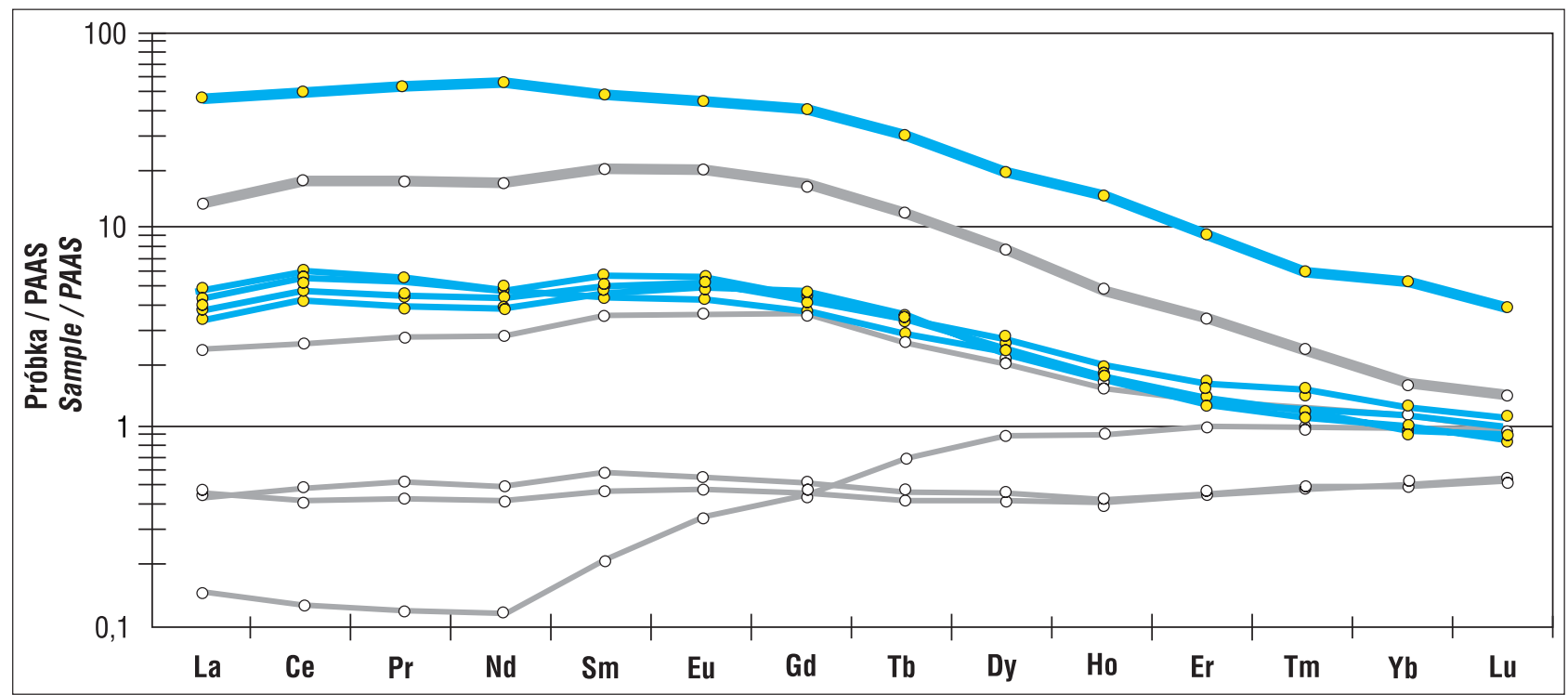

Ryc. 2. Zawartość REE w próbkach retyckiego odcinka profilu Niekłań PIG-1 znormalizowana do PAAS (wg McLennana, 2001). Linie pogrubione: szara - próbka Nk/178,4; niebieska - próbka Nk-5. Kolorem niebieskim zaznaczono próbki zbadane w ramach opracowania Mikulski i in. (2021), a próbki szare zaczerpnięto z wcześniejszej pracy (Mikulski i in., 2014)

Fig. 2. The content of REE in the samples of the Rhaetian section of the Niekłań PIG-1, profile normalized to PAAS (acc. to McLennan, 2001). Bold lines: grey - sample Nk / 178.4; blue - sample Nk-5. Samples analysed and reported by Mikulski et al. (2021) are marked in blue and samples marked in grey are derived from the earlier study (Mikulski et al., 2014)
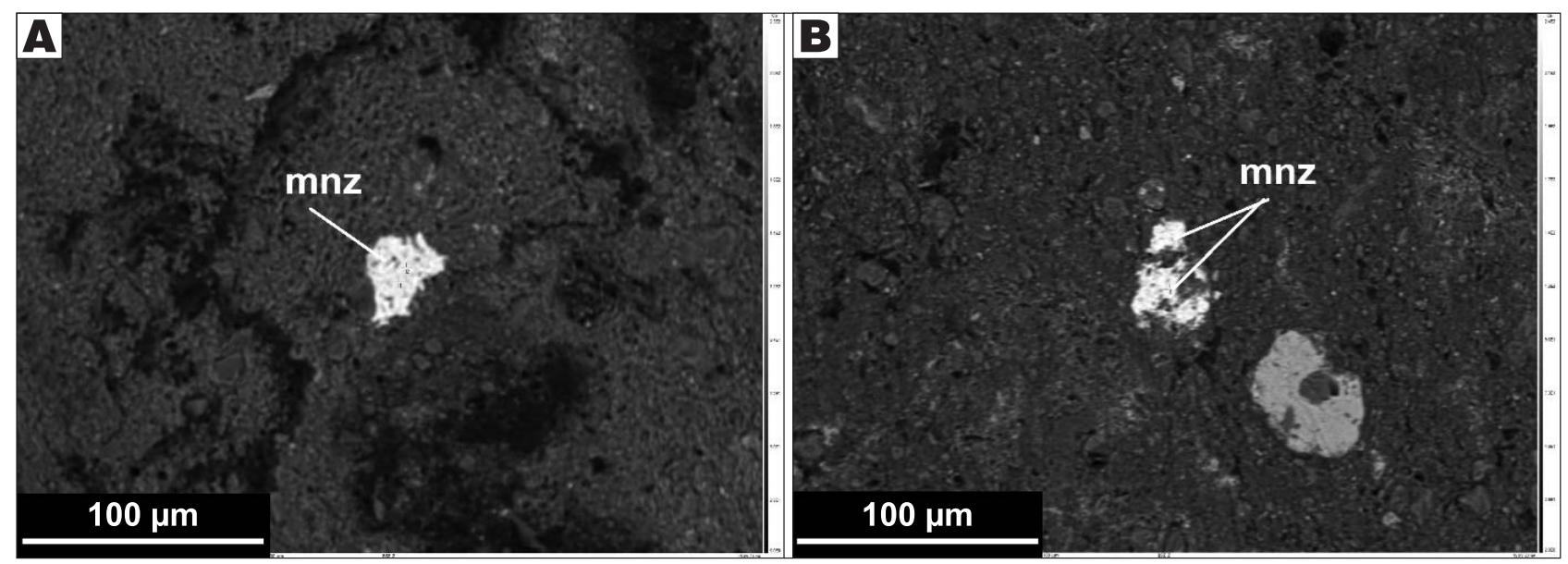

Ryc. 3. Obraz BSE formy występowania monacytów (mnz) w otworze Niekłań PIG-1. Próbka Nk-5, głębokość 179,05 m

Fig. 3. BSE image of monazite (mnz) occurrences in the Niekłań PIG-1 borehole. Sample Nk-5, depth $179.05 \mathrm{~m}$

Wzbogacenie w lantanowce (głównie lekkie) odnotowano w ok. 3-metrowym odcinku profilu w dolnej części warstw wielichowskich, wykazujących czerwono-szaro-zielone zabarwienie. Zawartość ta jest zmienna i może być różna nawet w sąsiadujących centymetrowych warstewkach skał drobnoziarnistych. Zawartość sumy REE waha się od ok. 0,07 do $0,95 \%$, co oznacza wzbogacenie od kilku- do kilkunastokrotnego, a w przypadku próbki z interwału głębokości 179,00-179,05 m jest ono nawet ponad 54-krotne wzbogacenie w stosunku do PAAS (ryc. 2). Średnia arytmetyczna $\Sigma$ REE dla interwału $177,4-179,05 \mathrm{~m}=0,261 \%$ $(\mathrm{n}=6)$, średnia arytmetyczna dla $\Sigma \mathrm{LREE}=0,237 \%$ (maks. $=0,98 \%$ ), dla $\Sigma$ HREE $=0,02 \%$, a średni stosunek zawartości LREE do HREE wynosi 13,2. Zakres zmienności zawartości dla poszczególnych REE jest szczególnie duży dla LREE. Wahają się one dla: Ce 320-4275 ppm, La 130-1940 ppm, Pr 34-514 ppm, Nd 126-1960 ppm i Sm 25-366 ppm. Zdecydowanie najwyższe zawartości zarówno dla LREE, jak i dla HREE odnotowano w próbce Nk-5 z głębokości 179,05 m.
Na podstawie wstępnych badań EPMA stwierdzono, że w tej najbogatszej próbce głównym nośnikiem REE jest prawdopodobnie monacyt [(Ce, $\mathrm{La}, \mathrm{Nd}) \mathrm{PO}_{4}$ ]. Największe rozpoznane ziarna posiadają średnicę maksymalnie do $80 \mu \mathrm{m}$, mają ksenomorficzną formę o nieregularnych, słabo wyraźnych krawędziach. Monacyty występują w formie rozproszonej w obrębie skały, nie wykazują tendencji do koncentrowania się (ryc. 3; tab. 1). Jednak konieczne są dalsze badania na mikrosondzie rentgenowskiej w celu zidentyfikowania również i innych nośników mineralnych REE w tych skałach.

\section{Odsłonięcie Miedary}

Innym interesującym miejscem jest środkowo-triasowe odsłonięcie w Miedarach k. Tarnowskich Gór, gdzie podwyższone zawartości REE stwierdzono w skondensowanych zielono-szarych, glaukonitowo-fosforanowych skałach piaszczysto-mułowcowych, zawierających faunę morską i szczątki kostne oraz nadległych czerwonych mułowcach 
Tab. 1. Podstawowe parametry statystyczne zawartości REE w monacytach (\% wag., $n=7)$ z otworu Niekłań PIG-1 Table 1. Basic statistical parameters of REE content in monazites $(w t \%, n=7)$ from the Niekłań PIG-1 borehole

\begin{tabular}{|l|c|c|c|c|c|c|c|c|c|}
\hline Parametr / Parameter & La & Ce & Pr & Nd & Sm & Eu & Gd & Dy & Y \\
\hline $\begin{array}{l}\text { Minimalna zawartość } \\
\text { Minimum content }\end{array}$ & 8,61 & 21,17 & 2,18 & 8,48 & 1,46 & 0,23 & 1,05 & 0,18 & 0,24 \\
\hline $\begin{array}{l}\text { Maksymalna zawartość } \\
\text { Maximum content }\end{array}$ & 12,50 & 25,25 & 2,66 & 10,87 & 1,76 & 0,43 & 1,43 & 0,53 & 1,08 \\
\hline $\begin{array}{l}\text { Średnia arytmetyczna } \\
\text { Arithmetic average }\end{array}$ & 9,93 & 22,57 & 2,44 & 9,45 & 1,62 & 0,31 & 1,24 & 0,46 & 0,84 \\
\hline
\end{tabular}

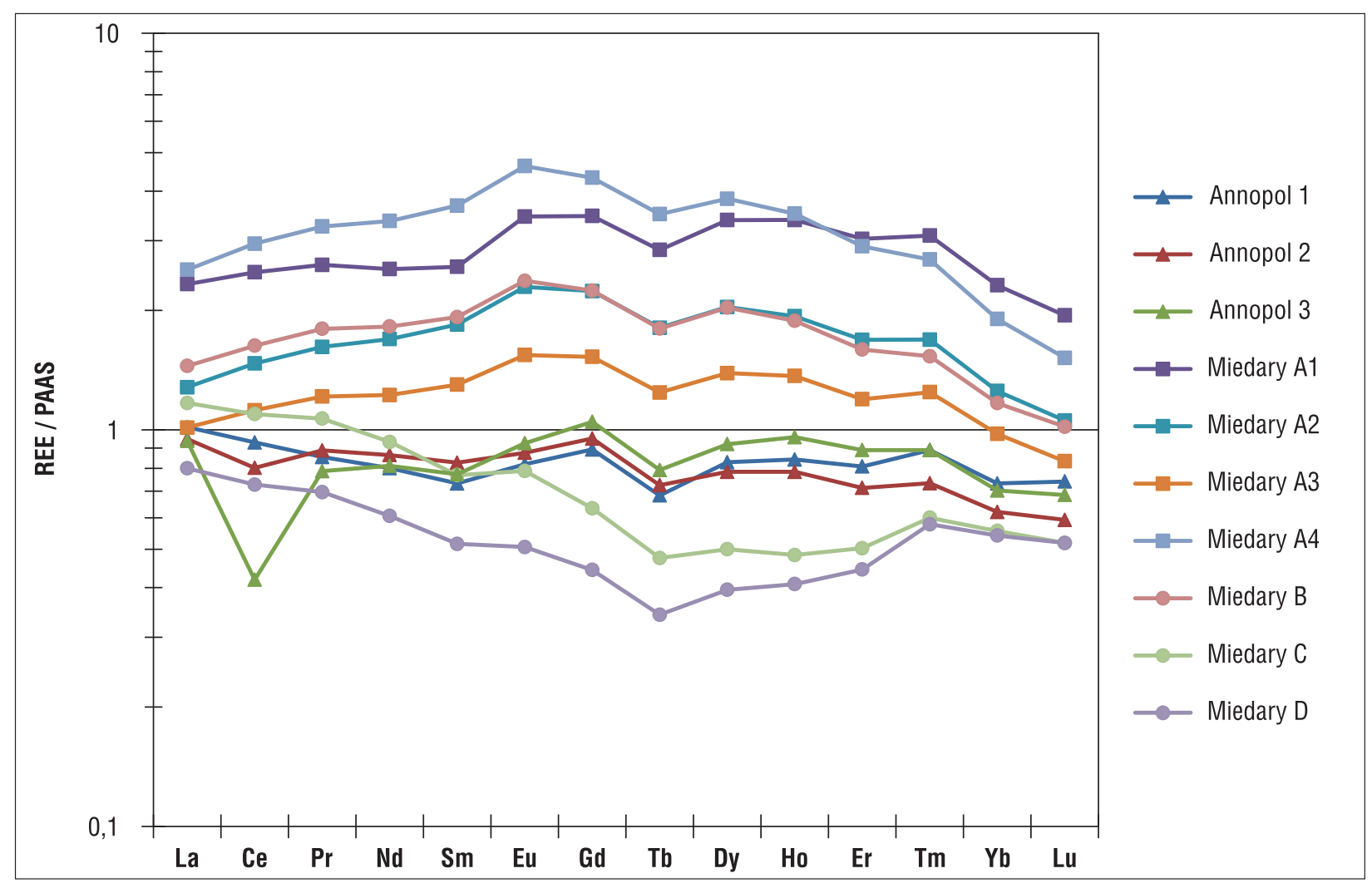

Ryc. 4. Dystrybucja REE w stosunku do PAAS (wg McLennana, 2001) w próbkach z profilu odsłonięcia w Miedarach i dla porównania z próbkami dolnokredowych osadów fosforytonośnych (alb-cenoman) z Annopola

Fig. 4. Distribution of REE versus PAAS (acc. to McLennan, 2001) in samples from the Miedary exposure profile in comparison with samples of Lower Cretaceous phosphate deposits (Albian-Cenomanian) from Annopol

z korzeniami roślin i mniej licznymi szczątkami kostnymi. Miejsce to jest bogate $\mathrm{w}$ fosfor dzięki nagromadzeniu szczątków kręgowców w strefie brzegowej epikontynentalnego morza, $\mathrm{z}$ przejściem w środowisko lądowe/sebha (Kowal-Linka, Bodzioch, 2017). Średnia arytmetyczna dla: $\Sigma$ REY $=385,8$ ppm $(\mathrm{n}=7 ; 143-709$ ppm $), \Sigma$ LREE $=$ $=282 \mathrm{ppm}(121,7-511,7 \mathrm{ppm})$, a dla HREY 104,4 ppm (22-197 ppm). Średnia dla LREE/HREE = 3,5. Znormalizowane zawartości REE w próbkach względem PAAS wykazały wzbogacenie od 2 do 5 razy w MREE (Eu, Gd, $\mathrm{Sm}, \mathrm{Tb}$ i Dy). W próbkach zaznacza się silna dodatnia anomalia Eu oraz ujemna anomalia Tb, co jest najprawdopodobniej związane z obecnością w nich głównego nośnika REE w postaci monacytu. W dwóch najbogatszych w REE próbkach (Miedary A4 i A1) także zawartości LREE (La-Nd-Eu) są od 2 do prawie 5 razy wyższe w stosunku do PAAS (ryc. 4).

\section{Hałdy po eksploatacji dolnokredowych fosforytów w Annopolu i Chałupkach}

Utwory fosforytonośne z mezozoicznego obrzeżenia Gór Świętokrzyskich nie były dotychczas przedmiotem szerszych badań w zakresie zawartości w nich REE (Substyk, 1961; Zglinicki i in., 2020, wraz z literatura), pomimo że w ubiegłym stuleciu udokumentowano 11 złóż fosforytów w utworach dolnokredowych oraz wskazano obszary dla nich perspektywiczne (Uberna, 1967; Gąsiewicz, 2020, wraz z literaturą). Eksploatacji fosforytów w Polsce, głównie w rejonie Annopola i Chałupek, zaniechano ze względów ekonomicznych w latach 70. ub.w. Fosforyty pochodzenia biogenicznego $\mathrm{w}$ formie konkrecji zasobnych w fosforany wapnia występują tam w płytkomorskich osadach kredowych na odcinku Radom-Iłża-Annopol-GościeradówModliborzyce (ryc. 1; Popov, Machalski, 2014). W albie na obszarze Annopola tworzyły się piaskowce i piaski z glaukonitem, w cenomanie - piaszczyste margle glaukonitowe, zaś we wczesnym turonie - wapienie $\mathrm{z}$ niewielką domieszką glaukonitu. Obszar Annopola znajdował się wtedy na podmorskim wyniesieniu, co sprawiło, że występujące na nim utwory są skondensowane. Liczne przerwy w sedymentacji oraz obfitość przynoszonych z lądu i osadzanych w morzu szczątków kostnych sprzyjały powstawaniu fosforytów. Główny pokład fosforytowy annopolskiego złoża powstał w albie na skutek podmorskiej 


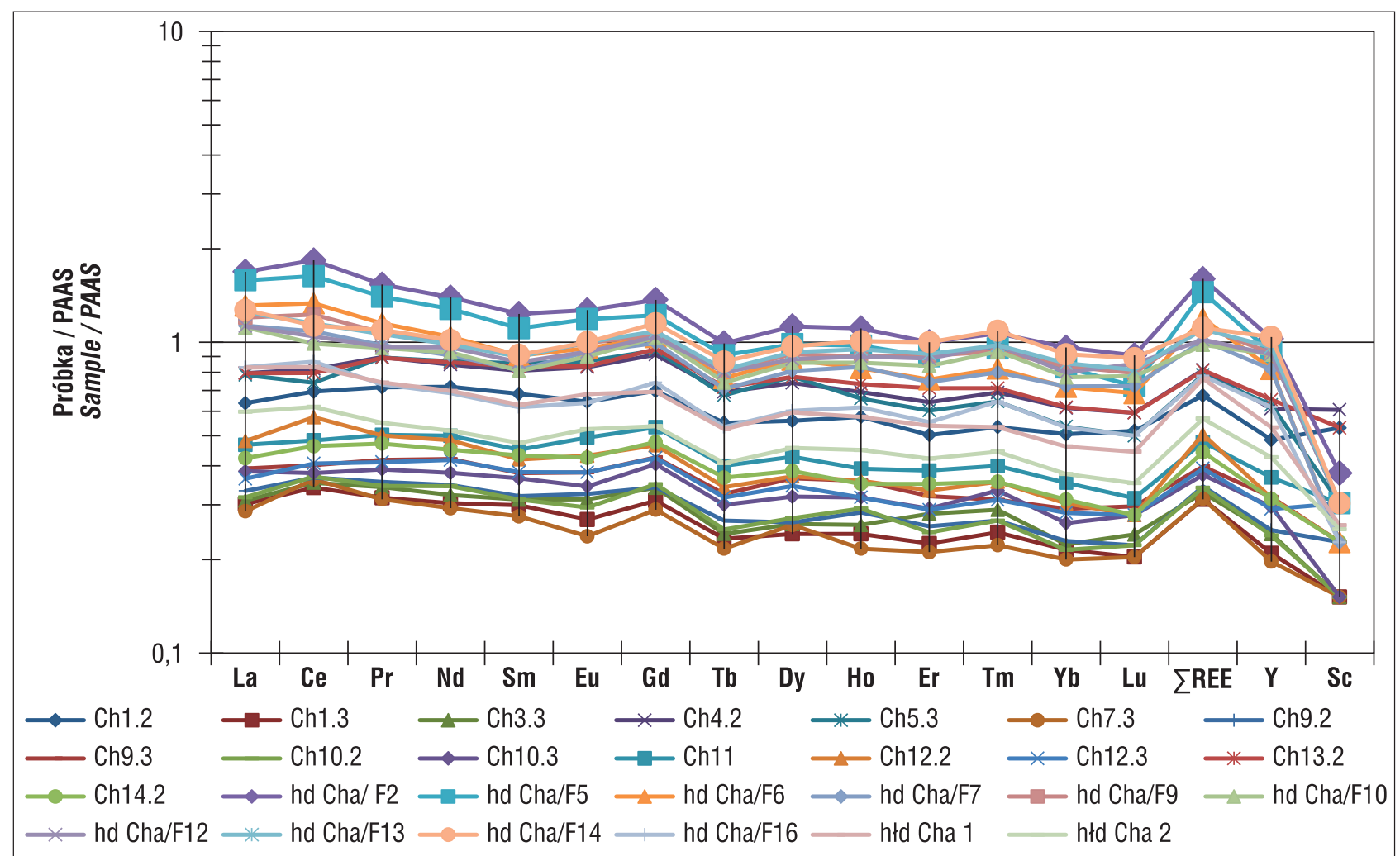

Ryc. 5. Dystrybucja REE w próbkach skał z dolnokredowych osadów fosforytonośnych z Chałupek w stosunku do PAAS (wg McLennana, 2001)

Fig. 5. Distribution of REE in rock samples from Lower Cretaceous phosphate sediments from Chałupki in relation to PAAS (acc. to McLennan, 2001)

erozji i redepozycji wcześniej utworzonych fosforytów przez prądy morskie (Marcinowski, Radwański, 1983).

Przedmiotem badań REE było 36 próbek dolnokredowych utworów fosforytonośnych pochodzących głównie z hałd w Chałupkach i Annopolu oraz pojedyncze próbki fosforytów pobrane w Ligocie k. Sieradza, Tumidaju oraz w okolicach Radomia. Średnie arytmetyczne zawartości we wszystkich zbadanych próbkach wynoszą odpowiednio: $\Sigma$ LREE $=133$ ppm $(\mathrm{n}=36$; zakres 55-284 ppm) i $\Sigma$ HREE $=16,5 \mathrm{ppm}(6-28 \mathrm{ppm})$, natomiast stosunek $\mathrm{LREE} / \mathrm{HREE}=8$ (zakres 5-10). Z kolei średnia arytmetyczna dla osadów fosforytonośnych z Annopola oraz innych miejsc k. Radomia wynosi dla $\Sigma$ REY $=200,1 \mathrm{ppm}(\mathrm{n}=9$, zakres 130-240 ppm), $\Sigma$ LREE = 144 ppm (96-184 ppm) oraz $\Sigma$ HREY $=55$ ppm $(33-66,6 \mathrm{ppm})$. Dla obszaru Chałupek średnie zawartości są nieco niższe, choć pojedyncze próbki miały najwyższe zawartości LREE w porównaniu do próbek z innych rejonów (ryc. 5). Dla Chałupek średnie arytmetyczne wynoszą: dla $\Sigma$ REY $=168 \mathrm{ppm}$ ( $\mathrm{n}=27$, zakres 70-354 ppm), $\Sigma$ LREE $=129,7 \mathrm{ppm}$ (55-284 ppm), $\Sigma$ HREY $=38$ ppm (14-70 ppm). Najwyższe średnie zawartości wykazują: Ce (62,5 ppm), La (30 ppm) i Nd (26 ppm). Znormalizowane zawartości REE w próbkach względem PAAS wykazały wzbogacenie w Ce w części próbek (maks. prawie do $2 \times$ ) oraz MREE (Sm-Gd, maks. $1,3 \times$ ) w kilku próbkach z Chałupek. Diagram normalizacji względem PAAS ujawnia pozytywną anomalię Gd oraz charakterystyczną ujemną anomalię dla Tb. Wzór krzywych jest w zasadzie identyczny jak dla osadów fosforytonośnych z rejonu Chałupek, jednak w próbkach tych prawie w ogóle niewidoczne jest wzbogacenie REE, Y i Sc w stosunku do PAAS.
Pseudokonkrecje fosforytowe cechują się nieregularną, strefową budową zewnętrzną i nieuporządkowaną budową wewnętrzną. Występują głównie w spoiwie o frakcji psamitowej $(0,1-2 \mathrm{~mm})$ lub rzadziej psamitowo-pelitowej (kwarcowo-illitowej) o śr. ziaren $<0,01 \mathrm{~mm}$. Szkielet ziarnowy konkrecji tworzy kwarc, glaukonit, skaleń potasowy, cyrkon i rutyl, natomiast spoiwo jest fosforanowe (frankolit) oraz kwarcowo-chlorytowo-ilaste. Nośnikiem REE w pseudokonkrecjach jest głównie frankolit oraz, jak wykazano w badaniach (EPMA), także monacyt. W spoiwie znajdują się również liczne sfosforytyzowane skamieniałości oraz uboga mineralizacja pirytowa. Ziarna monacytów mają do $50 \mu \mathrm{m}$ średnicy oraz cechują się hipautomorficzną formą z wyraźnie zaokrąglonymi krawędziami (ryc. 6). Monacyty te są wzbogacone w LREE (głównie Ce, La i Nd) (tab. 2).

\section{PODSUMOWANIE}

Przeprowadzone badania zawartości i rozmieszczenia pierwiastków ziem rzadkich w utworach osadowych w wybranych punktach obrzeżenia mezozoicznego Gór Świętokrzyskich wykazały lokalnie duże wzbogacenie w REE (Mikulski i in., 2021). Jeżeli porównamy średnie arytmetyczne zawartości REE w stosunku do PAAS (ryc. 7) w próbkach z najbardziej interesujących obszarów, to wyraźnie widoczne jest, że najwyższe średnie zawartości REE stwierdzono w prawie 3-metrowym mułowcowo-pylastym interwale profilu (głębokość ok. 177-180 m) archiwalnego otworu Niekłań PIG-1 w północnym obrzeżeniu Gór Świętokrzyskich. Występuje tam bardzo silne wzbogacenie $\mathrm{w}$ LREE $\mathrm{w}$ stosunku do PAAS. Jest ono powiązane z występującymi na tym odcinku poziomami glebowymi, 

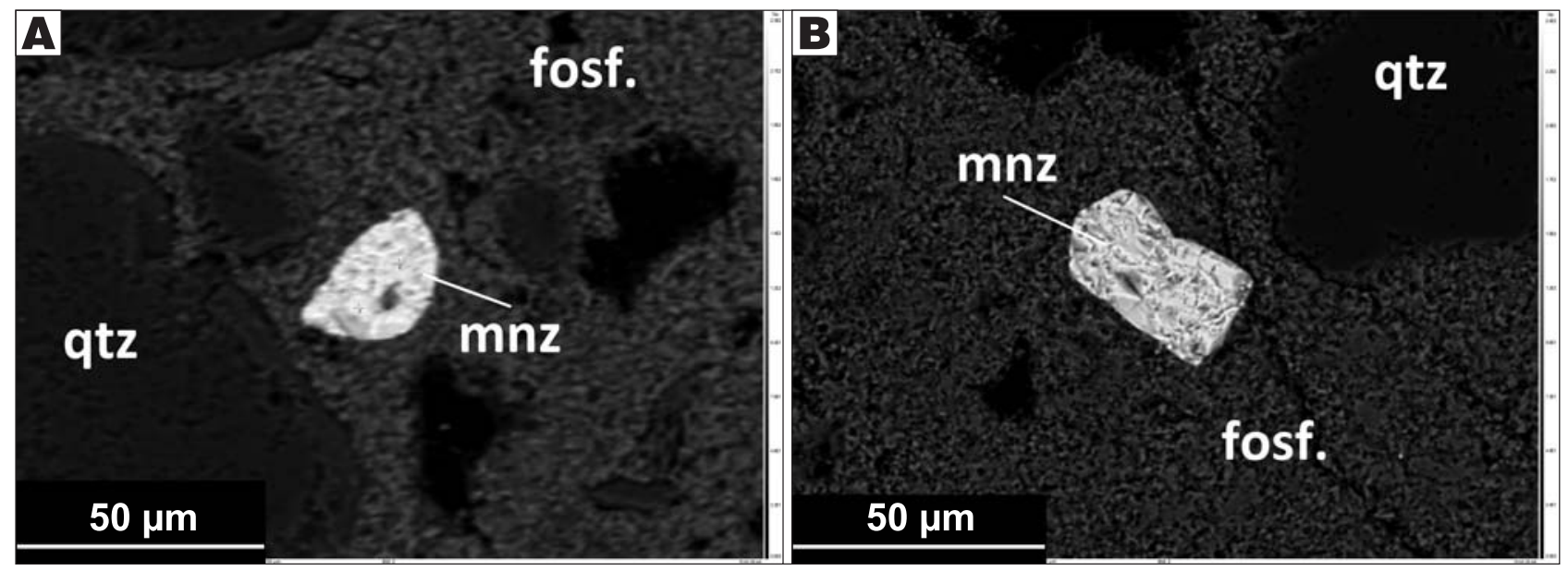

Ryc. 6. Obraz BSE form występowania monacytów w pseudokonkrecjach fosforytowych z Annopola (A) i Chałupek (B). Objaśnienia skrótów: mnz - monacyt, qtz - kwarc, fosf. - matrix fosforanowy (frankolit)

Fig. 6. BSE image of monazite occurrence in phosphate pseudoconcretions from Annopol (A) and Chałupki (B). Explanations of abbreviations: $\mathrm{mnz}$ - monazite, qtz - quartz, fosf. - phosphate matrix (francolite)

Tab. 2. Podstawowe parametry statystyczne zawartości REE w monacytach (\% wag., $\mathrm{n}=14$ ) z pseudokonkrecji fosforytowych z Annopola i Chałupek

Table 2. Basic statistical parameters of REE content in monazites (wt.\%, $\mathrm{n}=14$ ) in phosphorite pseudoconcretions from Annopol and Chałupki

\begin{tabular}{|l|c|c|c|c|c|c|c|c|c|}
\hline Parametr / Parameter & La & Ce & Pr & Nd & Sm & Eu & Gd & Dy & Y \\
\hline $\begin{array}{l}\text { Minimalna zawartość } \\
\text { Minimum content }\end{array}$ & 11,83 & 22,69 & 2,26 & 8,39 & 0,86 & 0,00 & 0,43 & 0,00 & 0,22 \\
\hline $\begin{array}{l}\text { Maksymalna zawartość } \\
\text { Maximum content }\end{array}$ & 14,99 & 26,89 & 2,89 & 9,90 & 1,69 & 0,19 & 1,39 & 0,72 & 2,22 \\
\hline $\begin{array}{l}\text { Średnia arytmetyczna } \\
\text { Arithmetic average }\end{array}$ & 12,86 & 24,40 & 2,51 & 9,33 & 1,35 & 0,06 & 1,03 & 0,38 & 1,10 \\
\hline
\end{tabular}

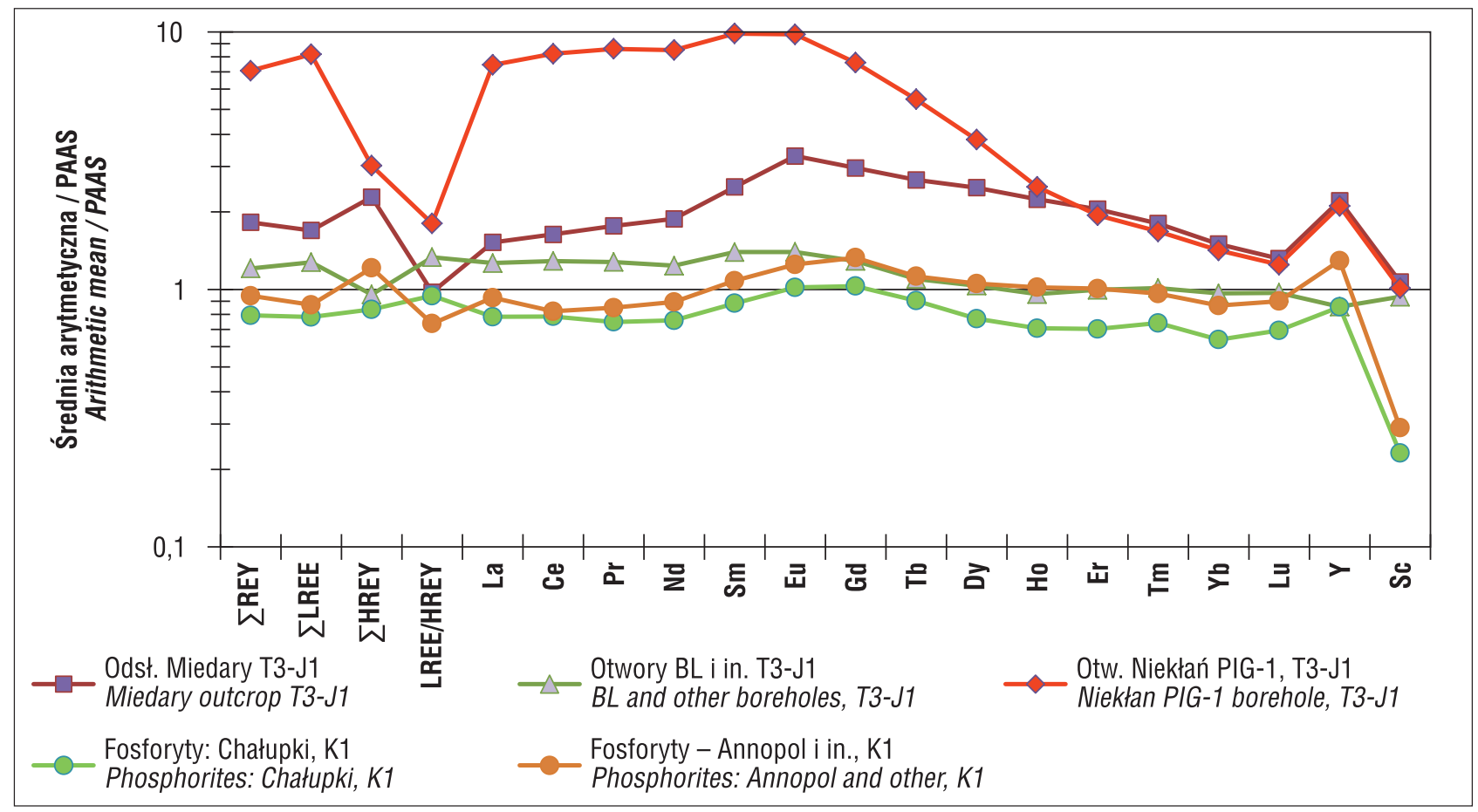

Ryc. 7. Wykres logarytmiczny porównania średnich arytmetycznych zawartości REE w zbadanych na ICP-MS próbkach skał osadowych z najciekawszych obszarów w obrzeżeniu mezozoicznym Gór Świętokrzyskich w stosunku do zawartości PAAS (wg McLennana, 2001) Fig. 7. Logarithmic graph showing comparison of REE arithmetic mean contents in samples of sedimentary rocks from the most interesting areas in the Mesozoic margin of the Holy Cross Mountains in relation to the PAAS content (acc. to McLennan, 2001)

wykazującymi w tej strefie liczne zmiany barw od czerwonych do szarozielonych. Wskazują one na zmienny potencjał redox, związany najprawdopodobniej z obecnością materii organicznej oraz zmianami zwierciadła płytkich wód podziemnych w warunkach półsuchego klimatu z sezonowymi opadami. Poziomy wzbogacone w LREE 
występują na głębokości od 177,15 do 180,10 m, a maksymalne zawartości REE w próbce dochodzą nawet do ok. $1 \%$. Dlatego wzbogacony w REE interwał należy uznać za potencjalnie perspektywiczny pod względem surowcowym.

W celu wyjaśnienia wzbogacenia w REE tego kopalnego poziomu glebowego oraz zasięgu jego rozprzestrzenienia w profilach pionowym i poziomym konieczne są dalsze prace. Z uwagi na fakt, że współczesne koncentracje złożowe REE w mułowcowych skałach osadowych znajdują się jedynie $\mathrm{w}$ zwietrzelinach laterytowych klimatu subtropikalnego (Bao, Zhao, 2008), to tego typu utwory są najbardziej perspektywiczne. Takie utwory występują w Polsce przede wszystkim w skałach asocjacji czerwonej triasu i są rozprzestrzenione na powierzchni głównie na obszarze śląskim (grupa kajpru) i świętokrzyskim (rejon otworu Niekłań PIG-1). Zawartości REE w odcinku profilu otworu Niekłań PIG-1 oraz we wzbogaconym w szczątki kostne profilu w odsłonięciu w Miedarach mogą być wynikiem wielu nakładających się procesów sedymentacyjnych, biochemicznych i fizyczno-chemicznych (np. lokalna domieszka mineralnych nośników REE, zmiana warunków pH i redoks, rozwój mikroorganizmów wskutek rozkładu materii organicznej w paleoglebach; Emmanuel i in., 2012) oraz zwiększona sorpcja pierwiastków przez minerały ilaste w kaolinitowo-smektytowym kopalnym poziomie wietrzeniowym.

Innym typem mineralizacji wymagającym dalszych kompleksowych i nowoczesnych prac prospekcyjnych sa wystapienia kredowych formacji fosforytonośnych w obrzeżeniu Gór Świętokrzyskich (Mikulski i in., 2021). Należy podkreślić, że na świecie potencjał złożowy formacji fosforytonośnych w zakresie zawartości REE jest silnie zróżnicowany (Emsbo i in., 2015). W obrzeżeniu Gór Świętokrzyskich sumaryczne zawartości REE są niskie, a w stosunku do PAAS zbliżone lub tylko lekko wzbogacone w LREE (Mikulski i in., 2014, 2021). Zawartości REE w niezwietrzałych fosforytach $\mathrm{z}$ serii złożowej powinny być wyższe niż $\mathrm{w}$ zbadanych próbkach pochodzących $\mathrm{z}$ hałd ( $\mathrm{REE}$ w zakresie 0,02-0,03\%) ze względu na remobilizację REE w strefie wietrzenia, choć należy podkreślić, że badane próbki pochodziły także z niedostępnych obecnie wyrobisk kopalnianych, w których efekty wietrzenia w ścianach wyrobisk były mocno ograniczone. Mimo stwierdzonych niskich zawartości REE, ze względu na już udokumentowane zasoby fosforytów oraz płytkie ich zaleganie oraz możliwość przeróbki i odzysku z nich REE, osady te mogą stanowić potencjalnie łatwo dostępne źródło REE. Konieczna jest kontynuacja przez PSG prac w tym zakresie. Należy również podjąć badania technologiczne możliwości odzysku $\mathrm{z}$ fosforytów pierwiastków ziem rzadkich.

Autorzy dziękują prof. Marcinowi Machalskiemu z Instytutu Paleobiologii Polskiej Akademii Nauk za udostępnienie próbek fosforytów z obecnie niedostępnych podziemnych wyrobisk górniczych z rejonu Annopola oraz prof. Tomaszowi Sulejowi $\mathrm{z}$ tego samego instytutu za pomoc w pracach terenowych i pozy- skaniu prób z odsłonięcia Miedary. Ponadto dziękujemy recenzentom (prof. K. Jarmołowicz-Szulc i prof. Z. Migaszewski) za uwagi, które umożliwiły poprawienie pierwotnej wersji artykułu. Przedstawione w tekście wyniki prac uzyskano w ramach projektu sfinansowanego ze środków NFOŚiGW zgodnie z umową dotacji nr 289/2018/Wn-07/FG-GO-DN/D z dnia 06.12.2018 r.

\section{LITERATURA}

BAO Z., ZHAO Z. 2008 - Geochemistry of mineralization with exchangeable REY in the weathering crusts of granitic rocks in South China. Ore Geol. Rev., 33: 519-53.

BRAŃSKI P. 2018 - Wstępna charakterystyka pierwiastków ziem rzadkich i innych pierwiastków śladowych w osadach drobnoziarnistych z pogranicza triasu i jury w dawnej bruździe śródpolskiej. Biul. Państw. Inst. Geol., 472: 255-270.

BRAŃSKI P., MIKULSKI S.Z. 2016 - Rare earth elements distribution in fine-grained deposits from the uppermost Triassic and Lower Jurassic of the Polish Basin: provenance and weathering in the source area. Geol. Quart., 60: 441-450.

EMMANUEL E.C., ANANTHI T., ANANDKUMAR B., MARUTHAMUTHU S. 2012 - Accumulation of rare earth elements by siderophore-forming Arthrobacter luteolus isolated from rare earth environment of Chavara, India. J. Biosci., 37 (1): 25-31.

EMSBO P., MCLAUGHLIN P.I., BREIT G.N., DU BRAY E.A., KOENING A.E. 2015 - Rare Earth Elements in sedimentary phosphate deposits: solution to the global REE crisis? Gondwana Res., 27 (2): 776-785.

GASIEWICZ A. 2020 - Fosforyty (Phosphorites). [W:] Szamałek K., Szuflicki M., Mizerski W. (red.), Bilans perspektywicznych zasobów kopalin Polski wg stanu na 31.12.2018 r. Państw. Inst. Geol., Warszawa: 233-236.

KOWAL-LINKA M., BODZIOCH A. 2017 - Genesis of the Lower Triassic bonebeds from Gogolin (S Poland): The impact of microbial mats on trapping of vertebrate remains. Palaeogeogr., Palaeoclimatol., Palaeoecol., 466: 38-58.

MARCINOWSKI R., RADWAŃSKI A. 1983 - The Mid-Cretaceous transgression onto the Central Polish Uplands (marginal part of the Central European Basin). Zitteliana, 10: 65-95.

MCLENNAN S.M. 2001 - Relationships between the trace element composition of sedimentary rocks and upper continental crust. Geochem., Geophys., Geosystem., 2 (4): 1-24.

MIKULSKI S.Z., OSZCZEPALSKI S., BRAŃSKI P., KOZDRÓJ W., MARKOWIAK M., KRAMARSKA R., CHMIELEWSKI A., SADŁOWSKA K., DAMRAT M. 2014 - Weryfikacja stanu wiedzy o mineralizacji metalami ziem rzadkich (REE) wraz z pilotażową oceną ich perspektyw złożowych w Polsce $\mathrm{z}$ wyłączeniem obszaru kratonu wschodnioeuropejskiego. Nar. Arch. Geol. Państw. Inst. Geol., nr inw. $1463 / 2016$.

MIKULSKI S.Z., MAŁEK R, CHMIELEWSKI A, SADŁOWSKA K, BRAŃSKI P., OSZCZEPALSKI S., MARKOWIAK M., PIEŃKOWSKI G., ZGLINICKI K., WISZNIEWSKA J., DYMOWSKI W., WOŁKOWICZ S., ZIELINSKI G., GIRO L., LECH D., GORECKA E., KARMASZ D. 2021 - Ocena potencjału złożowego REE w Polsce. Zadanie 4.2. Nar. Arch. Geol. Państw. Inst. Geol., nr inw. 1958/2021.

PIEŃKOWSKI G. 2004 - The epicontinental Lower Jurassic of Poland. Pol. Geol. Inst. Sp. Publ., 12: 1-152.

POPOV E.V., MACHALSKI M. 2014 - Late Albian chimaeroid fishes (Holocephali, Chimaeroidei) from Annopol, Poland. Cretaceous Res., 47: $1-18$.

SUBSTYK D. 1961 - Ziemie rzadkie w fosforytach polskich. Nar. Arch. Geol. Państw. Inst. Geol., nr inw. 14945.

UBERNA 1971 - Fosforyty w Polsce oraz możliwości występowania dalszych obszarów fosforytonośnych. Biul. Państ. Inst. Geol., 246 :7-46. ZGLINICKI K., SZAMAŁEK K., SALWA S., GÓRSKA I. 2020 - Dolnokredowe fosforyty z NE obrzeżenia Gór Świętokrzyskich jako potencjalne źródło REE - badania wstępne. Prz. Geol., 68 (7): 566-576.

Praca wpłynęła do redakcji 22.02.2021 r.

Akceptowano do druku 30.03.2021 r. 